\title{
Effects of the Abdominal Hollowing Technique Applied during Plank Exercises at Different Angles between Ground and the Humerus on Abdominal Stabilization Muscle Activity
}

\author{
Jeong Wook Kim', Min Chull Park² \\ 'Department of Physical Therapy, College of Health Sciences, Graduated School, Catholic University of Pusan, Busan; ${ }^{2}$ Department of Physical \\ Therapy, College of Health Sciences, Catholic University of Pusan, Busan, Korea
}

Purpose: This study examined the effects of the abdominal hollowing technique applied during plank exercises at different shoulder angles between the ground and the humerus on the abdominal muscle activity

Methods: The subjects were 36 male volunteers. They were randomized to perform plank exercises or plank exercises using the hollowing technique at $80^{\circ}, 90^{\circ}, 100^{\circ}$, and $110^{\circ}$ between the ground and the humerus. The abdominis muscles were measured using a surface electromyogram. Independent t-tests examined the changes in the activity of these muscles according to the two exercise methods at each angle. The changes in muscle activity were examined according to the selected angles by one-way analysis of variance.

Results: The activity of abdominal muscles was investigated according to the angle between the ground and the humerus during the plank exercise. As a result, the muscle activity increased significantly with decreasing angle in the rectus abdominis, external oblique, and internal oblique-transverse abdominis muscles $(p<0.05)$. In terms of the changes in abdominal muscle activity after hollowing plank exercises at the given angles between the ground and the humerus, an increase in angle resulted in a statistically significant increase in the rectus abdominis muscle activity $(p<0.05)$. The activities of the rectus abdominis, external oblique, and internal oblique/transverse abdominis muscles after hollowing plank exercises showed statistically significant increases $(p<0.05)$ compared to those after plank exercises.

Conclusion: The hollowing technique and the increase in the angle between the ground and the humerus may be an effective exercise method for increasing the muscle activity of the abdominis muscles.

Keywords: Plank, Hollowing, Angle between the ground and the humerus, Muscle activity

\section{서 론}

능동적인 근육의 힘은 몸통 안정화에 일차적인 기전을 제공한다. 근 육에 의한 몸통의 안정성을 흔히 중심 안정성(core stability)이라고 한 다. 이러한 안정성은 탈 안정화를 유발하는 외적인 힘들의 영향 하에 서도 몸통의 정적인 자세를 유지하게 하며, ${ }^{2}$ 주변 환경에 대해 몸통의 위치와 몸통뼈대안의 개별적 척추분절들을 안정화시킨다. 안정된 몸 통은 자세정렬을 최적화시키며, 척추뼈사이이음부(intervertebral joint)들 사이에 과도한 스트레스를 줄 수 있는 미세운동들을 제한한 다. 중심안정성에 관여된 근육이 균형적으로 작용하고 최적의 기능 을 발휘할 때, 척추는 안정성이 증가되어 외상으로부터 보호된다. ${ }^{4}$
중심안정성을 향상시키기 위한 운동은 자세에 따라 다양하게 실 시되고 있으며, ${ }^{5}$ 골반경사운동, ${ }^{6}$ 데드버그운동, ${ }^{7}$ 버드독운동, ${ }^{8}$ 밸런스 보드를 이용한 교각운동, 플랭크 ${ }^{10}$ 등의 방법들이 보고되고 있다. 그 중 플랭크운동은 닫힌사슬운동으로 사지의 먼쪽 분절이 지면에 고 정되어 자유롭게 움직일 수 없는 운동이다. 이러한 플랭크운동의 장 점으로는 고유감각과 운동감각에 큰 효과를 제공하고, 관절을 가로 지르는 많은 근육군이 동작을 조절하기 위해 활성화되므로 근육과 관절 내외의 많은 감각수용기들이 활성화된다. 또한 신체 분절 사이 의 상호적인 힘을 다른 관절에 전달하여 균형적인 자세 유지에 필요 한 협응운동을 일어나게 한다. ${ }^{10}$

플랭크운동은 엎드린 자세에서 위팔로 몸통을 지지하여 골반을
Received Mar 6, 2020 Revised Apr 17, 2020

Accepted Apr 27, 2020

Corresponding author Min chull Park

E-mail mcpark@cup.ac.kr
Copylight ( 2020 The Korean Society of Physical Therapy

This is an Open Access article distribute under the terms of the Creative Commons Attribution Non-commercial License (https:// creativecommons.org/license/by-nc/4.0.) which permits unrestricted non-commercial use, distribution, and reproduction in any medium, provided the original work is properly cited. 
중립으로 유지시키고, 머리부터 발끝까지 일직선을 유지하는 운동으 로 복부 안정화 근육 중 배곧은근과 배속빗근 - 배가로근에 비해 배바 깥빗근의 활성이 유발된다." 왜냐하면 위팔뼈를 지면에 받쳐 몸통을 지면으로부터 들어 올리는 동작을 취할 시, 중력에 의해 허리부위는 지면으로 휘어지게 되고, 골반은 앞 기울임되는 경향을 나타내는데 이때 골반을 중립으로 유지시키기 위해서 갈비뼈와 골반 사이에 부 착되어 골반을 뒤 돌림시키는 배바깥빗근의 활성이 증가되기 때문이 다. 또한 플랭크운동 시 배바깥빗근은 넓은등근, 앞톱니근과 부착점 이 맞물려 있으므로 배곧은근과 배속빗근에 비해 높은 활성도를 보 인다. ${ }^{12}$

몸통의 근육은 크게 대근육(global musle)과 소근육(local muscle) 으로 분류되며, ${ }^{13}$ 플랭크운동 시 활성도가 큰 배바깥빗근은 배곧은 근과함께 대근육으로 분류된다. 이는 표면에 위치하고, 큰 토크를 내 는 근육으로 몸통과 골반의 큰 움직임을 만드는 근육이다. 하지만 몸 통 안정화에 있어서 몸통의 가장 깊은 쪽에 위치하며, 등허리 근막에 부착되어 배내압을 증가시킴으로써 척추의 동적인 안정성을 제공하 는 코르셋 근육(corset muscle)으로 알려져 있는 배가로근의 활성이 더 중요하다. ${ }^{3}$ Hodge와 Richardson ${ }^{14}$ 에 의하면 엉덩관절을 벌림, 굽힘, 폄의 동작을 취할 시 몸통 근육의 근활성도를 측정한 결과, 하지 움 직임 이전에 배가로근이 먼저 수축한다고 하였다. 즉, 배가로근은 상 지와 하지 움직임 이전에 수축하여 몸통 안정성을 제공하는 근육이 다. ${ }^{15}$ 또한 요통을 가진 환자들에 있어서 배가로근의 수축시간이 지연 되었으며, 이는 상-하지의 운동 동안 몸통 안정화가 부적절해지는 원 인이 될 수 있다.16

이에 따라 요통을 예방하고 감소시키기 위한 치료적인 운동프로 그램으로 배가로근의 선택적인 수축을 위한 운동 방법들이 추천되 고 있다. 그 중 대표적인 운동 방법이 할로잉운동(Hollowing exercise) 이다. ${ }^{17}$ 이는 배벽을 안쪽으로 당김으로써 배가로근과 배속빗근을 수 축시켜 배내압을 증가시키는 방법으로 배가로근의 선택적인 활성에 좋은 운동이다.18 Bjerkefors 등 19 은 교각운동과 네발기기 자세에서 몸 통 안정화 운동 시행 시 할로잉 적용 유무에 따른 배가로근과 배곧은 근의 근활성도를 비교하였고, $\mathrm{Kim}^{20}$ 은 만성요통환자에게 할로잉기 법을 실시하여 통증지수와 배가로근의 두께 변화를 연구하였다. $\mathrm{Jang}^{21}$ 은 불안정한 지지면에서 할로잉운동과 몸통움크리기운동(curlup exercise)을 시행하여 배속빗근과 배가로근의 활성도를 연구하였 다. 위와 같이 몸통안정화운동과 할로잉기법을 적용한 연구는 많이 이루어졌으나 플랭크운동과 할로잉기법을 적용한 연구는 부족한 실 정이다.

플랭크동작과 관련된 운동역학을 살펴보면 지면과 위팔빼가 이루 는 각도의 변화는 오목위팔관절을 축으로 모멘트 팔의 길이 변화를 초래하며 어깨복합체의 안정성에 변화를 일으켜, 몸통 안정화 근육
의 활성도와 참여비율에 영향을 끼치게 된다.22 또한 위팔뼈와 지면 이 이루는 각도가 커짐에 따라 동반되는 어깨뼈의 위쪽돌림은 넓은 등근의 길이와 앞톱니근의 활성도에 영향을 끼쳐 부착점이 같은 배 바깥빗근의 활성도에 영향을 끼치게 된다. ${ }^{12}$ 이러한 점으로 플랭크동 작 시행 시 지지면과 위팔뼈가 이루는 각도를 다양하게 하여 몸통 안 정화 근육의 활성도를 알아볼 필요성이 있다. 플랭크와 관련된 선행 연구를 살펴보면, $\mathrm{Hwang}^{23}$ 은 어깨관절 각도를 $60^{\circ}, 90^{\circ}, 120^{\circ}$ 로 하여 배 근육들의 근활성도를 본 연구에서 각도가 클수록 배곧은근과 배속 빗근의 활성도가 커진다고 하였으며, Yoon'의 플랭크운동 시 복부 할 로잉과 브레이싱을 적용하여 비교한 연구에서 할로잉 적용이 배속빗 근의 근활성이 유의하게 증가하였다고 하였다. 이렇듯 플랭크와 관련 된 연구가 시행되었지만, $\mathrm{Hwang}^{23}$ 의 연구에서 어깨관절 $120^{\circ}$ 에서의 플랭크운동은 정확한 자세를 유지하는데 제한점이 있었다. 또한 지 면과 위팔빼가 이루는 각도 변화와 이에 따른 복부할로잉기법을 적 용하여 중심안정화에 작용하는 복부근육의 활성도 변화에 대한 연 구는 부족한 실정이다.

따라서 본 연구는 플랭크운동 시 지면과 위팔빼가 이루는 각도 변 화와 플랭크운동과 할로잉을 적용한 플랭크운동을 비교하여 복부근 육의 활성도를 조사함으로써 몸통 안정화 근육들의 활성도를 증가시 키는 효과적인 플랭크운동 방법을 제시하고자 하는데 목적이 있다.

\section{연구 방법}

\section{1. 연구대상}

본 연구는 부산에 거주하는 20-30대 남성 36명을 대상으로 실시하였 다. 연구에 앞서 대상자에게 연구에 대한 목적과 실험방법 등에 대해 충분히 설명하였고, 스스로 연구 참여에 동의한 자를 대상자로 선정 하였다. 대상자의 구체적인 선정 조건은 플랭크동작을 정확히 시행 할 수 있는 자, 신경계 손상이 없는 자, 최근 6개월간 정형외과적인 문 제가 없는 자로 하였다. 본 연구의 연구 대상자는 정상 성인 남성 36 명 으로 평균 나이는 $23.3 \pm 4$ 세, 평균 신장은 $175.9 \pm 5.5 \mathrm{~cm}$, 평균 몸무게 는 $73.1 \pm 7.1 \mathrm{~kg}$, 평균체질량 지수는 $23.8 \pm 2 \mathrm{~kg} / \mathrm{m}^{2}$ 이었다.

\section{2. 실험방법}

\section{1) 측정도구}

(1) 근전도(Electromyogram, EMG)

배곧은근, 배바깥빗근, 배속빗근. 배가로근의 근전도 신호를 측정하 기 위하여 8채널 표면 근전도장치(WEMG-8, LXM 5308 Laxtha, Korea)를 사용하였다. 이 장비는 송신기와 수신기로 구성되며 무선으로 주파수를 송 수신하여 데이터를 측정하는 장비이다. 보조 장비로는 노트북과 전극 케이블을 사용하였다. 
(2) 스마트폰 각도기(Smart Protractor)

지면과 위팔뼈가 이루는 각도를 측정하기 위해 Smart Tools co.에서 제공한 스마트폰 각도기(Smartphone Protractor v1.4) 어플을 Google player에서 다운받아사용하였다.

\section{2) 운동방법}

(1) 플랭크운동

본 연구에서 사용된 플랭크운동은 위팔과 지면이 이루는 각도를 기 준으로 4 가지 자세로 구성되었다. 플랭크운동 방법은 엎드린 자세에 서 위팔과 발가락으로 몸통을 들어 올려 머리, 등, 엉덩이, 하지가 일 직선이 되도록 유지 하였으며, 이때 위팔과 지면이 이루는 각도를 $80^{\circ}$ $90^{\circ}, 100^{\circ}, 110^{\circ}$ 로 하여 시행하였다(Figure 1). 각각의 운동은 5초간 3회
실시하였으며, 실험 순서는 무작위로 실시하였다. 처음과 끝 각 1 초를 제외한 중간 3 초간의 근활성도 자료를 분석에 사용하였고, 운동 시 피로를 방지하기 위하여 각 운동 후 1 분간의 휴식을 취하게 하였다.

\section{(2) 할로잉 플랭크운동}

실험에 앞서 올바른 할로잉 플랭크운동을 수행하기 위하여 갈고리 누운 자세(hooklying position)에서 압력 커프를 허리벼 위에 위치하도 록 하고 $70 \mathrm{mmHg}$ 로 유지시킨 후 배가로근을 수축함으로써 4-6 mm Hg 압력을 10 초 동안 감소하는 훈련을 10 회 반복하였다. 또한 골반 위앞 엉덩뼈가시의 내측을 촉진함으로써 배가로근의 능동적인 수축을 훈 련하였다. ${ }^{16}$ 할로잉 플랭크운동 방법은 엎드린 자세에서 위팔과 발가 락으로 몸통을 들어 올려 머리, 등, 엉덩이, 하지가 일직선이 되도록
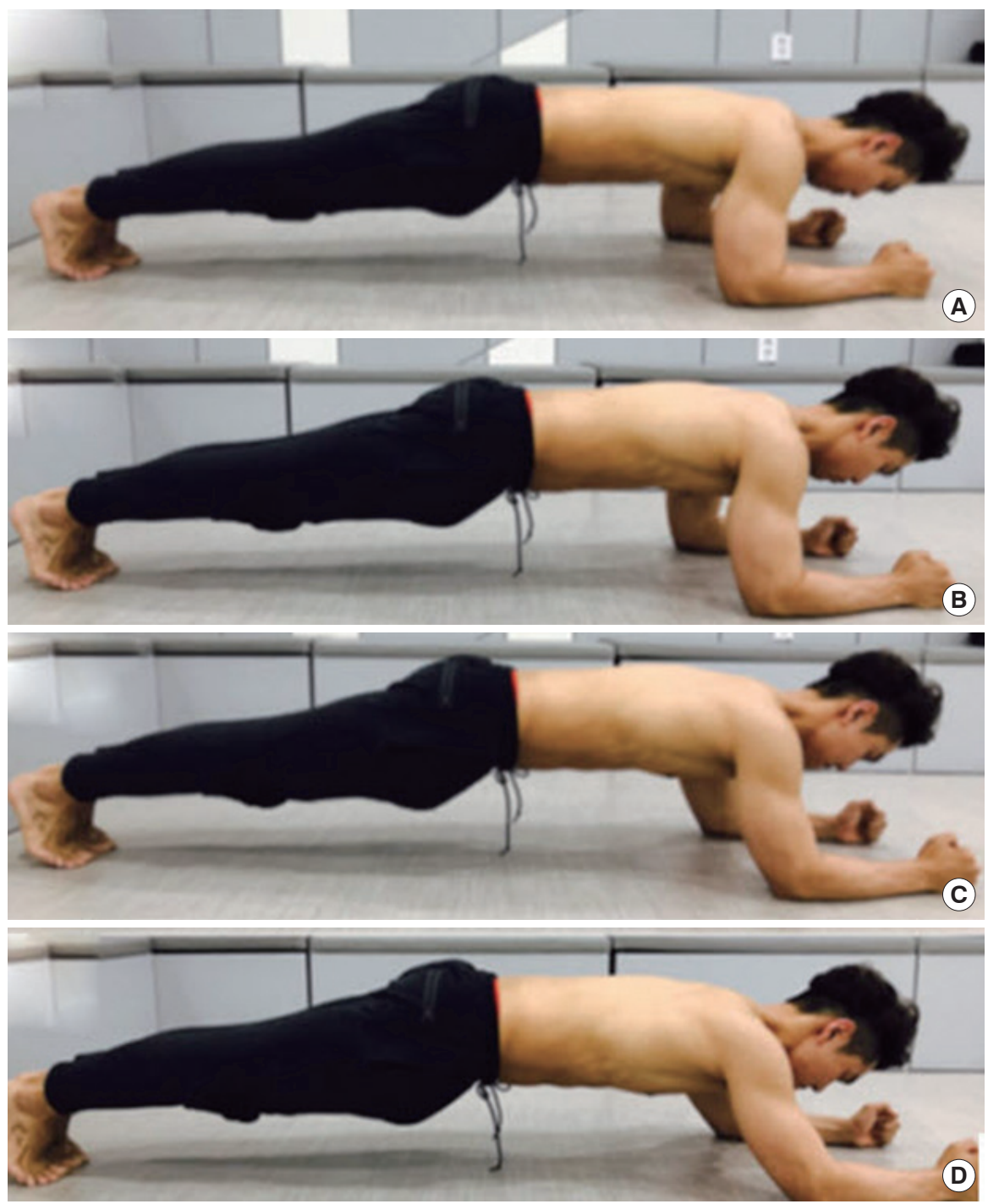

Figure 1. Plank exercise at different humerus angle on the ground.

A: Plank exercise at $80^{\circ}$ humerus angle on the ground, B: Plank exercise at $90^{\circ}$ humerus angle on the ground, $\mathrm{C}$ : Plank exercise at $100^{\circ}$ humerus angle on the ground, D: Plank exercise at $110^{\circ}$ humerus angle on the ground. 
유지한 상태에서 앞에서 연습한 할로잉을 지속적으로 유지하게 하였 다. 각각의 운동은 5 초간 3 회 실시하였으며, 실험 순서는 무작위로 실 시하였다. 처음과 끝 각 1 초를 제외한 중간 3 초간의 근활성도 자료를 분석에 사용하였고, 운동 시 피로를 방지하기 위하여 각 운동 후 1 분 간의 휴식을 취하게 하였다.

\section{3) 측정방법 \\ (1) 근전도 전극 부착}

배곧은근은 배꼽에서 외측으로 $1 \mathrm{~cm}$, 아래쪽으로 $2 \mathrm{~cm}$ 위치에 부착 하였고, ${ }^{24}$ 배속빗근. 배가로근은 위앞엉덩뼈가시(ASIS)와 나란하게 하여 내측으로 $2 \mathrm{~cm}$, 아래쪽으로 $2 \mathrm{~cm}$ 위치에 부착하였다. ${ }^{25}$ 배바깥 빗근은 배꼽 높이의 외측 $15 \mathrm{~cm}$ 위치에 부착하였다. ${ }^{26}$ 전극 패드 부착 부위는 인피던스로 인해 생기는 오차를 최소화하기 위해 면도하고 가는 사포로 2-3회 정도 문질러 각질을 제거한 후 알코올 솜으로 소 독하였다.

\section{(2) 근전도 신호의 기록 및 신호처리}

근활성도는 8채널 무선 근전도 장치(WEMG-8, LXM 5308 Laxtha, Korea)를 사용하였으며, Telescan 프로그램(Laxtha, USA)을 이용하여 분석하였다. 근전도 신호의 표본 추출률은 $1,024 \mathrm{~Hz}$, 대역통과필터 $20-500 \mathrm{~Hz}, 60 \mathrm{~Hz}$ 노치필터를 이용하여 필터링하였고, 표면 근전도 신 호 중에서 처음과 마지막 신호의 각 1 초를 제외하고 3 초 동안의 근전 도 값을 분석하였다. 각도별 할로잉 적용 유무에 따른 근 활성도 비교 는 지면과 위팔뼈가 이루는 각도를 $70^{\circ}$ 로 하여 플랭크동작을 시행 하 였을 때 값을 기준으로 하여 복부근육의 활성도를 \%RVC로 처리하 였다.

\section{4) 자료 처리 및 분석}

연구를 통해 얻어진 데이터는 SPSS for Windows ver 12.0을 사용하여 분석하였고, 모든 데이터 표기는 평균과 표준편차를 사용하였다. 각 도에 따른 개별 근육의 참여도와 활성도의 차이점을 알아보기 위해 일원배치분산분석(one-way ANOVA)을 실시하였으며, 집단 간 차이 는 Tukey HSD의 사후분석을 실시하였다. 또한 각도에 따른 개별 근 육의 할로잉 유무에 따른 활성도 변화는 독립표본 t-검정(independent t-test)을 하였다. 통계적 유의수준 $\alpha=0.05$ 로 설정하였다.

\section{결 과}

\section{1. 각도에 따른 복부근육의 활성도 비교}

\section{1) 플랭크운동 시 각도에 따른 복부근육의 활성도 비교}

위팔과 지지면이 이루는 각도에 따른 복부근육의 활성도를 비교한 결 과, 배곧은근, 배바깥빗근, 배속빗근 배가로근 모두 각도에 따라 유의 한 차이가 있었다 $(\mathrm{p}<0.05)$. 사후분석 결과 배곧은근은 $80^{\circ}$ 에 비해 $100^{\circ}$ 와 $110^{\circ}$ 에서 유의하게 근활성도가 증가하였고, $90^{\circ}$ 에 비해 $100^{\circ}$ 와 $110^{\circ}$ 에서 근활성도가 유의하게 증가하였다 $(\mathrm{p}<0.05)$. 배바깥빗근은 $80^{\circ}$ 에 비해 $110^{\circ}$ 에서 유의하게 근활성도가 증가하였고, $90^{\circ}$ 에 비해 $110^{\circ}$ 에서 유의하게 근활성도가 증가하였다 $(\mathrm{p}<0.05)$. 배속빗근 · 배가로근 은 $80^{\circ}$ 에 비해 $100^{\circ}$ 와 $110^{\circ}$ 에서 유의하게 근활성도가 증가하였고, $90^{\circ}$ 에 비해 $100^{\circ}$ 와 $110^{\circ}$ 에서 유의하게 근활성도가 증가하였으며, $100^{\circ}$ 에 비해 $110^{\circ}$ 에서 근활성도가 유의하게 증가하였다 $(\mathrm{p}<0.05)($ Table 1$)$.

\section{2) 할로잉 플랭크운동 시 각도에 따른 복부근육 활성도 비교}

할로잉 플랭크운동 시 각도에 따른 복부근육의 활성도를 비교한 결 과 배곧은근에서 유의한 차이가 있었다 $(\mathrm{p}<0.05)$. 사후분석을 실시한

Table 1. The comparison of trunk muscle EMG according to plank exercise

(unit: \%RVC)

\begin{tabular}{lllllll}
\hline & \multicolumn{1}{c}{$80^{\circ}$} & \multicolumn{1}{c}{$90^{\circ}$} & \multicolumn{1}{c}{$100^{\circ}$} & $110^{\circ}$ & $\mathrm{F}$ & $\mathrm{p}$ \\
\hline RA & $133.50 \pm 57.49^{\mathrm{a}}$ & $118.45 \pm 58.44^{\mathrm{a}}$ & $208.62 \pm 187.32^{\mathrm{b}}$ & $249.93 \pm 240.78^{\mathrm{b}}$ & 7.422 & $<.001^{*}$ \\
EO & $111.63 \pm 25.36^{\mathrm{a}}$ & $115.40 \pm 34.84^{\mathrm{a}}$ & $129.53 \pm 48.52$ & $146.89 \pm 49.98^{\mathrm{b}}$ & 8.738 & $<0.001^{*}$ \\
TrA IO & $125.42 \pm 35.64^{\mathrm{a}}$ & $110.79 \pm 39.15^{\mathrm{a}}$ & $169.08 \pm 89.20^{\mathrm{b}}$ & $205.81 \pm 98.93^{\mathrm{c}}$ & 17.119 & $<0.001^{*}$ \\
\hline
\end{tabular}

Mean $\pm S D$.

RA: rectus abdominis, EO: external oblique, IO: internal oblique, TrA: transverse abdominis. Different superscript letters $(a, b, c)$ indicate statistically significant $(p<0.05)$. *Significant difference $(p<0.05)$.

Table 2. The comparison of trunk muscle EMG according to hollowing plank exercise

(unit: \%RVC)

\begin{tabular}{lcccccc}
\hline & $80^{\circ}$ & $90^{\circ}$ & $100^{\circ}$ & $110^{\circ}$ & $\mathrm{F}$ & $\mathrm{p}$ \\
\hline RA & $179.61 \pm 86.48^{\mathrm{a}}$ & $161.49 \pm 77.93^{\mathrm{a}}$ & $227.84 \pm 141.56$ & $257.66 \pm 151.10^{\mathrm{b}}$ & 6.526 & $<0.001^{*}$ \\
EO & $176.59 \pm 105.51$ & $171.90 \pm 118.84$ & $193.72 \pm 130.80$ & $205.90 \pm 115.75$ & 0.73 & 0.573 \\
TrA IO & $332.10 \pm 429.57$ & $308.14 \pm 449.97$ & $339.67 \pm 457.12$ & $373.72 \pm 436.57$ & 0.13 & 0.971 \\
\hline
\end{tabular}


Table 3. The comparison of trunk muscle EMG according to plank exercise at angles between ground and the humerus

(unit: \%RVC)

\begin{tabular}{|c|c|c|c|c|c|}
\hline & & Plank & H-plank & $t$ & $p$ \\
\hline \multirow[t]{3}{*}{$80^{\circ}$} & RA & $133.5 \pm 57.49$ & $179.61 \pm 86.48$ & -2.664 & $0.010^{*}$ \\
\hline & EO & $111.63 \pm 25.36$ & $176.59 \pm 105.51$ & -3.592 & $0.001^{*}$ \\
\hline & $\operatorname{TrA} \cdot 10$ & $125.42 \pm 35.64$ & $332.1 \pm 429.57$ & -2.877 & $0.005^{*}$ \\
\hline \multirow[t]{3}{*}{$90^{\circ}$} & RA & $118.45 \pm 58.44$ & $161.49 \pm 77.93$ & -2.651 & $0.010^{*}$ \\
\hline & EO & $115.40 \pm 34.84$ & $171.90 \pm 118.84$ & -2.737 & $0.008^{*}$ \\
\hline & $\operatorname{TrA} \cdot 10$ & $110.79 \pm 39.15$ & $308.14 \pm 449.97$ & -2.622 & $0.011^{*}$ \\
\hline \multirow[t]{3}{*}{$100^{\circ}$} & RA & $208.62 \pm 187.32$ & $227.84 \pm 141.56$ & -0.491 & 0.625 \\
\hline & EO & $129.53 \pm 48.52$ & $193.72 \pm 130.08$ & -2.774 & $0.007^{*}$ \\
\hline & $\operatorname{TrA} \cdot 10$ & $169.08 \pm 89.20$ & $339.67 \pm 457.12$ & -2.198 & $0.034^{*}$ \\
\hline \multirow[t]{3}{*}{$110^{\circ}$} & RA & $249.93 \pm 240.78$ & $257.66 \pm 151.12$ & -0.163 & 0.871 \\
\hline & EO & $146.89 \pm 49.98$ & $205.9 \pm 115.75$ & -2.808 & $0.006^{*}$ \\
\hline & $\operatorname{TrA} \cdot 10$ & $205.81 \pm 98.93$ & $373.72 \pm 436.57$ & 0.068 & $0.030^{*}$ \\
\hline
\end{tabular}

Mean \pm SD.

RA: rectus abdominis, EO: external oblique, IO: internal oblique, TrA: transverse abdominis, H-plank: hollowing plank. *Significant difference $(p<0.05)$.

결과 배곧은근은 $80^{\circ}$ 에 비해 $110^{\circ}$ 에서 유의하게 근 활성도가 증가하 였고, $90^{\circ}$ 에 비해 $110^{\circ}$ 에서 유의하게 근 활성도가 증가하였다 $(\mathrm{p}<0.05)$ (Table 2).

\section{3) 각도와 운동방법에 따른 복부근육의 활성도 비교}

플랭크와 할로잉 플랭크를 비교한 결과 지면과 위팔뼈가 이루는 각 도가 $80^{\circ}, 90^{\circ}$ 일 때 배곧은근, 배바깥빗근, 배속빗근 배가로근 모두 근 활성도가 유의하게 증가하였다 $(\mathrm{p}<0.05)(T a b l e ~ 3)$. 지면과 위팔뼈가 이 루는 각도가 $100^{\circ}, 110^{\circ}$ 일 때 배바깥빗근, 배속빗근. 배가로근 모두 근 활성도가 유의하게 증가하였다 $(\mathrm{p}<0.05)$ (Table 3$)$.

\section{고 찰}

본 연구는 지면과 위팔뼈가 이루는 각도를 $80^{\circ}, 90^{\circ}, 100^{\circ}, 110^{\circ}$ 로 하여 각도에 따른 배곧은근, 배바깥빗근, 배가로근과 배속빗근의 활성도 에 미치는 영향을 알아보았다. 또한 배속빗근과 배가로근의 활성도 를 증진시키는 방안으로 할로잉기법을 적용하여 몸통 안정화 근육 의 근활성도를 연구하였다.

플랭크운동 시 지면과 위팔뼈가 이루는 각도를 $70^{\circ}$ 로 시행하였을 때를 기준으로 한 각도별 \%RVC를 측정한 결과 배곧은근은 $80^{\circ}$ 와 $100^{\circ}, 80^{\circ}$ 와 $110^{\circ}, 90^{\circ}$ 와 $100^{\circ}, 90^{\circ}$ 와 $110^{\circ}$ 간에 유의한 차이가 있었다. 배 바깥빗근은 $80^{\circ}$ 와 $100^{\circ}, 80^{\circ}$ 와 $110^{\circ}, 90^{\circ}$ 와 $110^{\circ}$ 에서 유의한 차이가 있었 으며, 배속빗근 배가로근 $80^{\circ}$ 와 $100^{\circ}, 80^{\circ}$ 와 $110^{\circ}, 90^{\circ}$ 와 $100^{\circ}, 90^{\circ}$ 와 $110^{\circ}$, $100^{\circ}$ 와 $110^{\circ}$ 에서 유의한 차이를 보였다. 이러한 결과는 지면과 위팔뼈 가 이루는 각도가 증가함에 따라 넓은등근은 신장되고 그로 인한 골 반의 앞돌림이 일어나므로 골반의 중립자세를 유지하기 위해 배바깥
빗근과 배곧은근의 활성이 증가한 것으로 여겨진다. 또한 지면과 위 팔뼈가 이루는 각도가 증가함에 따라 오목위팔관절을 축으로 한 지 렛팔의 길이가 증가하여, ${ }^{22}$ 어깨관절의 불안정성이 증가하였기 때문 에 몸통안정화 근육의 활성도가 증가한 것으로 여겨지며, 지면과 위 팔뼈가 이루는 각도 증가에 따른 어깨관절의 불안정성이 증가함에 따라, ${ }^{3}$ 어깨복합체를 안정화시키는 앞톱니근과 같은 근육의 수축에 영향을 미쳐 협력 수축을 통한 몸통 안정화 근육의 활성이 또한 증가 되었을 것이다. 또한 지면과 위팔뼈가 이루는 각도가 증가함에 따라 어깨뼈는 위쪽돌림이 일어나고 앞톱니근이 활성화됨에 따라 기시점 이 맞물려 있는 배바깥빗근의 활성도가 증가된 것으로 여겨지며, ${ }^{12}$ 지 면과 위팔뼈가 이루는 각도가 증가함에 따라 척추의 불안정성이 증 가하여, ${ }^{22}$ 척추 분절간 안정성을 높이기 위해 척추와 직접적으로 연 결되어있는 배속빗근. 배가로근의 근활성도가 유의하게 증가된 것으 로 생각된다. $\mathrm{Hwang}^{23}$ 의 어깨관절 각도를 $60^{\circ}, 90^{\circ}, 120^{\circ}$ 로 하여 복부 근육의 근활성도를 본 연구 또한 근육의 길이, 장력 관계에 의해 지면 과 위팔뼈가 이루는 각도 증가에 따라 배곧은근과 배속빗근의 활성 도가 유의하게 증가하였다고 보고하였다.

플랭크운동과 할로잉 플랭크운동 시 몸통 안정화 근육의 근활성 도를 비교한 결과 할로잉 플랭크자세에서 위팔뼈와 지지면이 이루는 각도가 증가함에 따라 배곧은근, 배바깥빗근, 배가로근과 배속빗근 의 근활성도가 증가하였다. 이는 할로잉기법을 시행함에 있어 배내압 을 증가시키기 위해 몸통 안정화 근육들이 더 크게 협력 수축하였기 때문이다. 그러므로 플랭크동작에 있어 운동 강도를 조절하기 위해 위팔과 지면이 이루는 각도변화뿐만 아니라, 할로잉기법 적용 또한 고려될 수 있다고 사료된다.

할로잉과 관련된 선행연구를 살펴보면 Mannion 등27은 할로잉운동 
은 휴식기와 비교하여 배가로근의 두께를 $9 \%$ 증가시킨다고 하였고, Yoon'은 플랭크운동 시 할로잉기법을 적용하였을 때 배속빗근의 활 성이 유의하게 증가하였다고 하였다. $\mathrm{Kim}^{28}$ 에 의하면 몸통 안정화 운 동과 함께 시행한 할로잉운동은 배가로근. 배속빗근의 신경적 적응 능력을 향상시켜 척추안정성을 증가시켰다고 보고하였다. Vezina와 Hubley-Kozey ${ }^{29}$, Drysdale 등 30 은 복부 할로잉 운동을 하였을 때 골반 경사 운동을 시행하였을 때보다 배곧은근과 배바깥빗근의 근활성도 가 유의하게 감소하였다고 하였으며, 몸움크리기운동(curl-up exercise) 을 시행하였을 때 복부 할로잉기법 적용 유무에 따른 몸통 안정화 근 육의 활성도를 연구한 결과 복부 할로잉기법을 적용하였을 때 배곧은 근의 근활성도는 유의하게 감소하였고, 배속빗근과 배가로근의 근활 성도가 유의하게 증가하였다. ${ }^{21}$ 이는 배속빗근과 배가로근의 근활성 도에 있어 복부 할로잉운동만 시행하는 것보다 다른 근육과 협력 수 축을 하였을 때 더 큰 활성화를 보인다는 것을 의미한다.

본 연구를 통해 몸통 안정화 운동을 효율적으로 시행하기 위해 플 랭크운동 시 할로잉기법의 적용이 더 효과적이라는 것을 알게 되었 고, 위팔과 지면이 이루는 각도가 증가함에 따라 몸통 안정화 근육들 의 근활성도가 증가함을 알 수 있었다. 따라서 플랭크운동 시 할로잉 기법을 적용하여 $110^{\circ}$ 에서 실행하는 것이 몸통 안정화 근육들의 활성 도를 증가시키는 데 효과적이다. 이는 복부근육들의 활성도를 증가시 키는 효과적인 운동방법에 대한 기초자료로 활용할 수 있을 것이다.

\section{ACKNOWLEDGEMENTS}

본 연구는 김정욱의 2017 학년도 학위논문의 내용을 일부 발췌하였음

\section{REFERENCES}

1. Brown SH, Vera-Garcia FJ, McGill SM. Effect of abdominal muscle coactivation on the externally preloaded trunk: variation in motor control and its effect on spine stability. Spine. 2006;31:387-93.

2. Barr KP, Griggs M, Cadby T. Lumbar stabilization: a review of core concepts and current literature, part 2. Am J Phys Med Rehabil. 2007;86(1):7280 .

3. Neumann DA. Kinesiology of the musculoskeletal system: foundation for physical rehabilitation. 2th edition. Mosby, 2011.

4. Cholewicki J, VanVlient JJ. Relative contribution of trunk muscles to the stability of the lumbar spine during isometric exertions. Clin Biomech (Bristol, Avon). 4th. 2002:17(2):99-105.

5. Ekstrom RA, Donatelli RA, Carp KC. Electromyographic analysis of core trunk, hip, and thigh muscles during 9 rehabilitation exercises. J Orthop Sports Phys Ther. 2007;37(12):754-62.

6. Elia DS, Bohannon RW, Carneron D, Albro RC. Dynamic pelvic stabilization during hip flexion: a comparison study. J Orthop Sports Phys Ther. 1996;24(1):30-6.
7. Akuthota V, Nadler SF. Core strengthening. Archives of Physical Medicine and Rehabilitation. 2004;85(1):86-92.

8. Czaprowski D, Afleltowicz A, Gę.bicka A et al. Abdominal muscle EMG-activity during bridge exercises on stable and unstable surfaces. Phys Ther Sport. 2014;15(3):162-8.

9. Yoon HD. Comparison trunk muscle activation according to trunk stabilization by plank exercise. Catholic University of Daegu. Dissertation of Master's Degree. 2017.

10. Um KM, Kang SH, Kim DD. Musculoskeletal rehabilitation. KunjaPublication, 2005:145-6.

11. Schellenberg KL, Lang JM, Chan KM et al. A clinical tool for office assessment of lumbarspine stabilization endurance: prone and supin bridge maneuvers. American Journal of Physical Medicine \& Rehabilitation. 2007:86(5):380-6.

12. Kwon OY, Kwack MS, Kim MS. Diagnosis and treatment of movement impairment syndromes. Jungdam-Publication. 2010:101-2.

13. Bermark A. Stability of the lumbar spine. a study in mechanical engineering. Acta Orthop Scand Suppl. 1889;230:1-54.

14. Hodges PW, Richardson CA. Contraction of the abdominal muscles associated with movement of the lower limb. Phys Ther. 1997;77(2):13242.

15. O'Sullivan P, Twomey L, Allison G et al. Altered patterns of abdominal muscle activation in patients with chronic low back pain. Austr J Phys. 1997;43(2):91-8.

16. Kim K, Kim SY, Kim HD. Assessment and treatment of muscle imbalance: the Janda approach. Yeongmunsa. 2012.

17. Richardson CA, Jull GA. Muscle control-pain control, what exercises would you prescribe? Man Ther. 1995;1(1):2-10.

18. Kisner C, Colby L. Therapeutic exercise. 6th edition. Philadelphia. LA, 2016.

19. Bjerkefors A, Ekblom MM, Josefsson K et al. Deep and superficial abdominal muscle activation during trunk stabilization exercises with and without instruction to hollow. Man Ther. 2010;15(5):502-7.

20. Kim HI. Case study of aplication on ADIM of patient with chronic low back pain for contraction training of transversus abdominis. Journal of Korean Academy of Orthopaedic Manual Therapy. 2001;17(2):49-55.

21. Jang HJ. The effect of abdominal-hollowing exercises on trunk muscle activity during curl-up exercise on different support surface. In-je University. Dissertation of Master's Degree. 2011.

22. Brunnstrom S, Lehmkuhl LD, Smith LK. Brunnstrom's Clinical Kinesiology. 6th edition. FA Davis, 2014.

23. Hwang JH. Comparsion trunk muscle activation according to shoulder angle by Plank exercise. Catholic University of Daegu. Dissertation of Master's Degree. 2014.

24. Ng JK, Kippers V, Richardson CA. Muscle fibre orientation of abdominal muscles and suggested surface EMG electrode positioons. Electromyogr Clin Neurophysiol. 1998;38(1):51-8.

25. Marshall P, Murphy B. The validity and reliability of surface EMG to assess the neuromuscular response of the abdominal muscles to rapid limb movement. J Electromyogr Kinesiol. 2003;13(5):477-89.

26. Stevens VK, Coorevits PL, Bouche KG et al. The influence of specific training on trunk muscle recruitment patterns in healthy subjects during stabilization exercises. Man Ther. 2007;12(3):271-9.

27. Mannion AF, Pulkovski N, Toma V et al. Abdominal musclesize and 
symmetry atrestand during abdominalhollowing exercises in healthy control subjects. J Anat. 2008;213(2):173-82.

28. Kim MS. The comparison of effects for hollowing and bracing strategy with spinal stabilization exercise for trunk strength, static balance and low back disability to the elderly women with non-specific chronic low back pain. Korea University. Dissertation of Master's Degree. 2015.
29. Vezina MJ, Hubley-Kozey CL. Muscle activation in therapeutic exercises to improve trunk stability. Arch Phys Med Rehabil. 2000;81(10):1370-9.

30. Drysdale CL, Earl JE, Hertel J. Surface electromyographic activity of the abdominal muscles during pelvic-tilt and abdominal-hollowing exercises. J Athl Train. 2004;39(1):32-6. 